\title{
4: Myanmar's GDP growth and investment: lessons from a historical perspective
}

\author{
U Myint
}

\section{Introduction}

According to official figures, Myanmar has achieved double-digit gross domestic product (GDP) growth rates every year for the six years from 2000 to 2005. These figures have proved controversial. A related and another contentious issue regarding Myanmar's economic performance in the same period is that high real GDP growth rates have been achieved with comparatively low gross domestic investment (GDI) to GDP ratios.

In order to gain a proper perspective on these issues, one approach is to use cross-sectional data for a particular period to obtain a comparative view of Myanmar's performance vis-a-vis the performance of its neighbours in the same period. The comparative approach has been adopted frequently and has been useful in analysing developments in Myanmar's economic and social situation through the years.

Myanmar has, however, a rich tradition of data collection and analysis. National accounts data, for example, go as far back as 1948, when the country gained independence, and even beyond. In addition to cross-sectional analysis, therefore, the available time-series data could be used to review Myanmar's recent economic performance, as reflected in official data of the country's past experience. Such a brief review is attempted in this chapter with specific attention devoted to real GDP growth and GDI.

\section{Myanmar's 'good' performance from a comparative viewpoint}

Appendix Table 4.1 gives GDP growth rates for the first six years of the new millennium for 19 developing Asian countries, including Myanmar. The countries in the table are grouped into four categories - namely: 1) newly industrialising economies (NIEs); 2) second-tier NIEs; 3) other developing countries; and 4) least-developed countries. The table shows that Myanmar's GDP growth rate in real terms has been good compared with other countries in the region; Myanmar's average growth rate was 12.9 per cent a year for this period. Since the average annual growth rates for the four categories of developing Asian countries ranged 
between 4.5 per cent and 5.8 per cent for the period, Myanmar's growth performance has been more than double the growth rates of these countries.

The fact that Myanmar's higher real GDP growth rates have been achieved with considerably lower GDI to GDP ratios, compared with other countries in the region, is illustrated in Appendix Table 4.2. That table shows that while the GDI/GDP ratio averaged 24 per cent per annum for the period 2000-05 for other Asian countries, Myanmar's GDI/GDP ratio averaged about 12 per cent per annum. This means that Myanmar has been able to achieve a real GDP growth rate double the rate of its neighbours, with half their GDI ratios.

\section{Reservations about Myanmar's growth performance}

Many observers, within the country and abroad, have expressed reservations about Myanmar's official growth rates. The International Monetary Fund (IMF), for example, has a conservative outlook regarding Myanmar's economic performance in recent years, because it is of the view that other regional countries in a similar situation as Myanmar have not experienced such robust growth in the same period. The IMF has defined 'similarity' in terms of a low level of development, a large agricultural sector, a pervasive role of the State in the economy and a recent history of conflict. Bangladesh, Cambodia, Laos and Vietnam were identified as countries having such attributes. It was pointed out that Myanmar, despite its high official growth figures, did not fare well when its social indicators were compared with those for these countries. It also did not measure up to these countries in terms of per capita GDP in US dollars. Moreover, the IMF had difficulty reconciling Myanmar's high agricultural growth with its official figures on harvested acreage, irrigated areas and the reported decline in the use of fertilisers and pesticides.

Similarly, high industrial growth does not seem to be consistent with the relatively low increase in industrial power consumption, manufacturing's use of petroleum products and the decline in capital-goods imports. The IMF concludes that all these imply an implausibly large increase in productive efficiency. The IMF expected near-zero growth for Myanmar in the fiscal year 2003/04, based on its belief that constraints that would arise from a low level of imported inputs, structural rigidities, delayed effects of sanctions and the banking crisis. In sharp contrast with IMF expectations, Myanmar authorities estimated 13.8 per cent growth for that year.

\section{Review of Myanmar's economic performance using time-series data}

The time-series data for the review cover the whole of Myanmar's post-independence era -57 years, from independence in 1948 to the fiscal year 2005/06, the last year for which data were available. For convenience and ease of presentation, data are presented in Appendix Tables 4.3-4.8, with each 
covering a decade: the 1950s, 1960s, 1970s, 1980s, 1990s and the first decade of the new millennium. What they reveal is highlighted below.

\section{Double-digit real GDP growth, 1948-2005}

Sustained double-digit growth in real GDP began in the fiscal year 1999/2000 and continued for seven years up to 2005 (and could continue for several years more). Such sustained double-digit growth represents a sharp break with the country's development experience in its entire post-independence period, extending across half a century. Until 1999/2000, which ushered in the new millennium, there had never been double-digit real GDP growth that extended across two consecutive years.

During the 50 years since independence, there have been five instances of double-digit GDP growth: twice in the 1950s (1950 and 1956) and three times in the 1960s (1962, 1964 and 1967). In all these instances, a double-digit growth year has always been either immediately preceded by or immediately followed by a negative-growth year. For instance, real growth of 12.9 per cent in 1950 was preceded by a 10 per cent real GDP decline in 1948 and a further 5 per cent fall in 1949. Similarly, 13 per cent growth in 1962 was followed by a decline of 6.1 per cent in 1963. For three decades preceding the fiscal year 1999/2000, there had not been a single instance of double-digit real GDP growth.

\section{Real GDP growth and the GDI/GDP ratio, 1948-2005}

Table 4.1 summarises how real GDP growth and the GDI/GDP ratio have changed in Myanmar in the past five decades and in the early years of the new millennium.

Table 4.1 Myanmar: real GDP growth rates and the GDI/GDP ratio, 1950/51-2004/05

\begin{tabular}{|l|l|l|}
\hline \multicolumn{1}{|c|}{ Fiscal years } & Average GDP growth rate (\%) & Average GDI/GDP ratio (\%) \\
\hline $1950 / 51-1959 / 60$ & 5.8 & 18.9 \\
\hline $1961 / 62-1970 / 71$ & 3.5 & 12.2 \\
\hline $1970 / 71-1979 / 80$ & 3.9 & 12.8 \\
\hline $1980 / 81-1989 / 90$ & 1.9 & 16.1 \\
\hline $1990 / 91-1999 / 2000$ & 6.1 & 13.6 \\
\hline $1999 / 2000-2004 / 05$ & 12.6 & 11.8 \\
\hline
\end{tabular}

From Table 4.1, we can say that in the 1950s, Myanmar was not a least-developed country, and, with a GDI/GDP ratio of 19 per cent, it achieved an average annual growth rate of about 6 per cent.

In the next two decades (the 1960s and 1970s), as a consequence of command-style economic management under military rule, self-imposed isolation and the 'Burmese way to socialism', the economy deteriorated. Real GDP growth was reduced to 3-4 per cent per annum, while the GDI/GDP ratio fell to between 12 and 13 per cent. 
The 1980s were, economically, the worst in Myanmar's post-independence history. Although the decade started off well with real GDP growing between 5 per cent and 8 per cent and the GDI/GDP ratio reaching 21-22 per cent, the political turmoil and social disturbances in the latter half of the decade overshadowed the good beginning. For the decade as a whole, therefore, GDP growth averaged only 1.9 per cent per annum - slightly below the 2 per cent growth in population. The GDI/GDP ratio, however, remained relatively high for this period, averaging 16 per cent per annum (Appendix Table 4.7). We could also recall that in 1987, Myanmar applied for and was granted 'least-developed country' status by the United Nations and, in 1988, a new regime came to power that abandoned the 'Burmese way to socialism' and adopted a 'market-oriented' approach for the country to become a 'modern developed nation'.

A claim could be made that economic reforms in the first half of the 1990s enabled the country to attain a respectable 6 per cent growth in this decade. This better performance has, however, been achieved with a relatively stagnant GDI/GDP ratio of about 13 per cent.

What conclusion can be drawn, then, regarding Myanmar's growth experience from independence in 1948 up to the end of the 1990s? If we wish to be unkind, we can say that Myanmar is a subsistence agricultural economy, relying on a few commodities, with a pre-industrial economic structure, which has no shock absorbers to cushion the impact of events originating within and outside the country. Natural and human-made disasters, therefore, windfalls from the bounty of nature and commodity booms that resulted from such events as the Korean War largely determined the state of the economy, rather than factors such as the GDI/GDP ratio.

Such unkind views can, however, no longer hold with the official data for Myanmar's economic performance coming into the new millennium. In biblical times, it was possible for a country's economy to enjoy seven fat years in a row and then to suffer seven lean years in a row. Not anymore! Global warming, a growing menace, has brought with it climate change that has made weather volatile and erratic. There is no way a country can expect to have seven consecutive years of good harvests in the twenty-first century. The fact that real GDP growth in Myanmar doubled from 6 per cent in the 1990s to 12 per cent at the start of the new millennium, and that this double-digit growth was sustained for seven years while the GDI/GDP ratio fell to 11-12 per cent, deserves some explanation. There are probably two reasons for this: politics and arithmetic.

Regarding politics, the powers that be in the country have a fixation with high GDP growth rates, which are believed to indicate the country's growing prosperity and wellbeing. These growth rates have therefore become highly 
politicised and, in the process, credibility and good sense have fallen by the wayside.

As for arithmetic, social and economic indicators for the country are normally expressed as a ratio of GDP. Now, when the GDP that is used as a denominator in these indicators is padded, inflated and made to rise proportionately more than the numerator, this will introduce a downward bias to the indicators. It is therefore not surprising that an unusually high real GDP growth rate, as reflected in official national account statistics, in the new millennium has led to a fall in the GDI/GDP ratio. This also accounts for the pathetically low export/GDP ratio and industrial value added/GDP ratio, as well as many other social and economic indicators, which are embarrassingly far below such indicators in other countries in the region.

This has not always been the case in Myanmar's post-independence history. For instance, Table 4.2 provides the ratio of exports to GDP for the 1950s, when the country did not suffer from politically inspired GDP figures. This ratio averaged 22.6 per cent per annum for the decade, which was consistent with such ratios for any country in the world judged to be in a similar economic situation as Myanmar at that time.

Table 4.2 Myanmar: GDP, exports and the export/GDP ratio, 1950/51-1959/60 (million kyat, current prices)

\begin{tabular}{|l|r|r|r|r|r|r|r|r|r|r|r|r|}
\hline Fiscal year & $1950 / 1951 / 1952 /$ & $1953 /$ & $1954 /$ & $1955 /$ & $1956 / 1957 /$ & $1958 /$ & $1959 /$ & Total & Average \\
& 1951 & 1952 & 1953 & 1954 & 1955 & 1956 & 1957 & 1958 & 1959 & 1960 & & \\
\hline GDP & 3690 & 4084 & 4620 & 4589 & 4813 & 5144 & 5452 & 5384 & 5626 & 5999 & 49 & 4940 \\
& & & & & & & & & & & 401 & \\
\hline Exports & 975 & 1093 & 1292 & 1066 & 1116 & 1174 & 1183 & 894 & 1002 & 1179 & 10 & 1097 \\
& & & & & & & & & & & 974 & \\
\hline Exports/GDP (\%) & 26.42 & 26.76 & 27.97 & 23.23 & 23.19 & 22.82 & 21.70 & 16.60 & 17.81 & 19.65 & 226 & 22.62 \\
\hline
\end{tabular}

Source: Government of Burma, Economic Survey of Burma, 1955, 1959 and 1963.

The same exercise reported in Table 4.2, using official figures for the new millennium, yields Table 4.3, with an export/GDP ratio reduced to 0.44 per cent - a percentage that will take us back to a pre-colonial and pre-industrial era, definitely before King Mindon's reign (1853-78), when Myanmar had little regular commerce with the outside world.

Table 4.3 Myanmar: GDP, exports and the export/GDP ratio, 2000/01-2002/03 (million kyat, current prices)

\begin{tabular}{|l|r|r|r|r|r|}
\hline Fiscal year & \multicolumn{1}{|c|}{$\mathbf{2 0 0 0 / 0 1}$} & \multicolumn{1}{|c|}{$2001 / 02$} & \multicolumn{1}{|c|}{$2002 / 03$} & \multicolumn{1}{l|}{ lotal } & \multicolumn{1}{l|}{ Average } \\
\hline GDP & 2552733 & 3548472 & 5527000 & 11628205 & 3876068 \\
\hline Exports & 12627 & 16350 & 19955 & 48932 & 16311 \\
\hline Exports/GDP ratio (\%) & 0.49 & 0.46 & 0.36 & 1.31 & 0.44 \\
\hline
\end{tabular}

Source: Central Statistical Organisation, Statistical Yearbook 2003: Table 14.02, p. 315. 


\section{Conclusion}

The above observations lead us to conclude that Myanmar has two choices in terms of its economic data:

- continue to stick with exceptionally high and unbelievable real GDP growth rates and the associated embarrassingly poor social and economic indicators

- revise real GDP growth rates to more realistic, accurate and reasonable levels and have less embarrassing social and economic indicators.

What to choose? I think we have stuck with the first option long enough; it has been counterproductive. The good image that a high growth rate is expected to convey has proved elusive. The public data are largely ignored and are probably thought not fit to be printed, so do not appear in the major regional and world economic reviews and reports. On the other hand, the embarrassing social and economic indicators they generate attract publicity, are talked about, highlighted and published. This is not good politics.

It is time therefore to move to the second option. Improvement in quality, accuracy, credibility, reliability, timeliness and the availability of economic and social statistical data and information will be an essential first step in building a modern developed nation. 


\section{Appendix}

\section{Appendix Table 4.1 GDP growth rates, selected Asian countries, 2000-05 (per cent)}

\begin{tabular}{|c|c|c|c|c|c|c|c|}
\hline Economy & 2000 & 2001 & 2002 & 2003 & 2004 & 2005 & 2000tarag \\
\hline \multicolumn{8}{|l|}{ I. Newly industrialising economies (NIEs) } \\
\hline Republic of Korea & 8.5 & 3.8 & 7.0 & 3.1 & 4.6 & 4.1 & 5.2 \\
\hline Hong Kong & 10.2 & 0.5 & 1.9 & 3.2 & 8.1 & 5.7 & 4.9 \\
\hline Singapore & 9.7 & -1.8 & 3.2 & 1.4 & 8.4 & 4.1 & 4.2 \\
\hline Taiwan & 5.8 & -2.2 & 3.9 & 3.3 & 5.7 & 4.2 & 3.5 \\
\hline Average NIEs & 8.6 & 0.1 & 4.0 & 2.8 & 6.7 & 4.5 & 4.5 \\
\hline \multicolumn{8}{|l|}{ II. Second-tier NIEs } \\
\hline Malaysia & 8.9 & 0.3 & 4.1 & 5.3 & 7.1 & 5.7 & 5.2 \\
\hline Thailand & 4.8 & 2.2 & 5.3 & 6.9 & 6.1 & 5.6 & 5.2 \\
\hline Indonesia & 4.9 & 3.8 & 4.3 & 5.0 & 5.1 & 5.5 & 4.8 \\
\hline Average second-tier NIEs & 6.2 & 2.1 & 4.6 & 5.7 & 6.1 & 5.6 & 5.1 \\
\hline \multicolumn{8}{|l|}{ III. Other developing countries } \\
\hline China & 8.0 & 7.5 & 8.3 & 9.3 & 9.5 & 8.5 & 8.5 \\
\hline Vietnam & 6.1 & 5.8 & 6.4 & 7.1 & 7.5 & 7.6 & 6.8 \\
\hline India & 4.4 & 5.8 & 4.0 & 8.5 & 6.5 & 6.9 & 6.0 \\
\hline Pakistan & 3.9 & 1.8 & 3.1 & 5.1 & 6.4 & 7.0 & 4.6 \\
\hline Philippines & 4.4 & 1.8 & 4.3 & 4.7 & 6.1 & 5.0 & 4.4 \\
\hline Sri Lanka & 6.0 & -1.5 & 4.0 & 5.9 & 5.5 & 5.2 & 4.2 \\
\hline Average other developing countries & 5.5 & 3.5 & 5.0 & 6.8 & 6.9 & 6.7 & 5.8 \\
\hline \multicolumn{8}{|l|}{ IV. Least-developed countries } \\
\hline Bhutan & 5.5 & 7.1 & 6.7 & 6.5 & 7.0 & 8.0 & 6.8 \\
\hline Laos & 5.8 & 5.8 & 5.9 & 5.9 & 6.5 & 7.0 & 6.2 \\
\hline Bangladesh & 5.9 & 5.3 & 4.4 & 5.3 & 5.5 & 5.3 & 5.3 \\
\hline Cambodia & 7.0 & 5.6 & 5.5 & 5.2 & 6.0 & 2.3 & 5.3 \\
\hline Nepal & 6.0 & 4.8 & -0.4 & 2.9 & 3.3 & 3.0 & 3.3 \\
\hline Average least-developed countries & 6.0 & 5.7 & 4.4 & 5.2 & 5.7 & 5.1 & 5.4 \\
\hline $\begin{array}{l}\text { Average all selected (18) countries } \\
\text { above }\end{array}$ & 6.6 & 2.9 & 4.5 & 5.1 & 6.4 & 5.5 & 5.2 \\
\hline Myanmar & 13.7 & 11.3 & 12.0 & 13.8 & 13.6 & 13.2 & 12.9 \\
\hline
\end{tabular}

Source: Asian Development Bank 2005, Key Indicators of Developing Asian and Pacific Countries, Online Edition, Asian Development Bank, Manila. Source for Myanmar: Ministry of National Planning and Economic Development, Yangon. 
Dictatorship, disorder and decline in Myanmar

\section{Appendix Table 4.2 GDI, selected Asian countries, 2000-05 (per cent of GDP)}

\begin{tabular}{|c|c|c|c|c|c|c|c|}
\hline Economy & 2000 & 2001 & 2002 & 2003 & 2004 & 2005 & $\begin{array}{l}2000-05 \\
\text { (average) }\end{array}$ \\
\hline \multicolumn{8}{|l|}{ I. Newly industrialising economies (NIEs) } \\
\hline Republic of Korea & 28.3 & 27.0 & 26.1 & 29.4 & 30.2 & 30.1 & 28.5 \\
\hline Hong Kong & 28.1 & 25.3 & 22.8 & 21.9 & 21.8 & 20.5 & 23.4 \\
\hline Singapore & 32.0 & 26.5 & 23.7 & 15.6 & 19.4 & 18.6 & 22.6 \\
\hline Taiwan & 22.9 & 18.4 & 17.4 & 17.4 & 21.5 & 20.2 & 19.6 \\
\hline Average NIEs & 27.8 & 24.3 & 22.5 & 21.1 & 23.2 & 22.4 & 23.6 \\
\hline \multicolumn{8}{|l|}{ II. Second-tier NIEs } \\
\hline Malaysia & 27.2 & 23.9 & 24.0 & 21.6 & 22.6 & 19.8 & 23.2 \\
\hline Thailand & 22.8 & 24.1 & 23.8 & 24.9 & 27.1 & 31.6 & 25.7 \\
\hline Indonesia & 16.1 & 23.5 & 20.4 & 17.3 & 21.3 & 21.3 & 20.0 \\
\hline Average second-tier NIEs & 22.0 & 23.8 & 22.7 & 21.3 & 23.7 & 24.2 & 23.0 \\
\hline \multicolumn{8}{|l|}{ III. Other developing countries } \\
\hline China & 36.3 & 34.2 & 35.2 & 38.0 & 39.3 & 43.5 & 37.8 \\
\hline Vietnam & 23.9 & 31.2 & 33.2 & 35.4 & 35.5 & 35.4 & 32.4 \\
\hline India & 24.4 & 23.0 & 25.3 & 27.2 & 30.1 & - & 26.0 \\
\hline Pakistan & 16.0 & 17.2 & 16.8 & 16.9 & 17.3 & 16.8 & 16.8 \\
\hline Philippines & 29.1 & 19.0 & 17.7 & 16.7 & 17.1 & 15.7 & 19.2 \\
\hline Sri Lanka & 28.1 & 22.0 & 21.3 & 22.3 & 25.8 & 27.0 & 24.4 \\
\hline Average other developing countries & 26.3 & 24.4 & 24.9 & 26.1 & 27.5 & 27.7 & 26.2 \\
\hline \multicolumn{8}{|l|}{ IV. Least-developed countries } \\
\hline Laos & 20.5 & 21.0 & 21.2 & 21.2 & 22.0 & 22.0 & 21.3 \\
\hline Bangladesh & 23.0 & 23.1 & 23.1 & 23.4 & 24.0 & 24.4 & 23.5 \\
\hline Cambodia & 17.3 & 18.7 & 20.1 & 25.1 & 25.8 & 26.4 & 22.2 \\
\hline Nepal & 24.3 & 24.1 & 24.2 & 25.8 & 26.4 & 25.7 & 25.1 \\
\hline Average least-developed countries & 21.3 & 21.7 & 22.2 & 23.9 & 24.6 & 24.6 & 23.1 \\
\hline $\begin{array}{l}\text { Average all selected (17) countries } \\
\text { above }\end{array}$ & 24.4 & 23.6 & 23.1 & 23.1 & 24.8 & 24.7 & 24.0 \\
\hline Myanmar & 12.4 & 11.6 & 10.4 & 11.0 & 12.0 & - & 11.5 \\
\hline
\end{tabular}

Source: Asian Development Bank 2004 and 2006, Asian Development Outlook. Source for Myanmar: Ministry of National Planning and Economic Development, Yangon. 
Appendix Table 4.3 Myanmar: GDP at 2000/01 constant prices, and GDI as ratio of GDP, 1999/2000-2005/06

\begin{tabular}{|c|c|c|c|}
\hline Fiscal year & GDP (million kyat) & $\begin{array}{c}\text { GDP change from previous } \\
\text { year (\%) }\end{array}$ & GDI/GDP ratio (\%) \\
\hline $\mathbf{1 9 9 9 / 2 0 0 0}$ & 2246035 & 10.9 & 13.4 \\
\hline $\mathbf{2 0 0 0 / 0 1}$ & 2553742 & 13.7 & 12.4 \\
\hline $\mathbf{2 0 0 1 / 0 2}$ & 2842314 & 11.3 & 11.6 \\
\hline $\mathbf{2 0 0 2 / 0 3}$ & 3183392 & 12.0 & 10.4 \\
\hline $\mathbf{2 0 0 3 / 0 4}$ & 3622700 & 13.8 & 11.0 \\
\hline $\mathbf{2 0 0 4 / 0 5}$ & 4115387 & 13.6 & n.a. \\
\hline $\mathbf{2 0 0 5 / 0 6}$ & 4658619 & 13.2 & - \\
\hline Total & & 88.5 & $11.8^{\text {a }}$ \\
\hline Average & & 12.6 & \\
\hline
\end{tabular}

a average for years $1999 / 00$ to $2004 / 05$

Notes: GDI = total investment + stock changes; GDP figures are calculated from data in the Statistical Yearbook and using growth rates given in tables in Paras (11) and (14) of Myanmar's Economic Development; GDI figure for 2003/04 is from UNCTAD 2005, Handbook of Statistics, Table 7.3, p. 349; GDI figure for 2004/05 is from UNCTAD 2006, LDC Report 2006, Annex Table 6, p. 316.

Sources: Ministry of National Planning and Economic Development 2006, Myanmar's Economic Development, December 2006; Central Statistical Organisation 2003, Statistical Yearbook.

\section{Appendix Table 4.4 Myanmar: GDP at 1947/48 constant prices, and GDI as ratio of GDP, 1948/49-1960/61}

\begin{tabular}{|c|c|c|c|}
\hline Fiscal year & GDP (million kyat) & $\begin{array}{c}\text { GDP change from previous } \\
\text { year (\%) }\end{array}$ & GDI/GDP ratio (\%) \\
\hline $\mathbf{1 9 4 8 / 4 9}$ & 3200 & -10.0 & n.a. \\
\hline $\mathbf{1 9 4 9 / 5 0}$ & 3038 & -5.1 & n.a. \\
\hline $\mathbf{1 9 5 0 / 5 1}$ & 3431 & 12.9 & 12.9 \\
\hline $\mathbf{1 9 5 1 / 5 2}$ & 3636 & 6.0 & 18.2 \\
\hline $\mathbf{1 9 5 2 / 5 3}$ & 3899 & 7.2 & 22.0 \\
\hline $\mathbf{1 9 5 3 / 5 4}$ & 4073 & 4.5 & 21.0 \\
\hline $\mathbf{1 9 5 4 / 5 5}$ & 4294 & 5.4 & 18.0 \\
\hline $\mathbf{1 9 5 5 / 5 6}$ & 4456 & 3.8 & 19.9 \\
\hline $\mathbf{1 9 5 6 / 5 7}$ & 4934 & 10.7 & 22.0 \\
\hline $\mathbf{1 9 5 7 / 5 8}$ & 4778 & -3.2 & 19.4 \\
\hline $\mathbf{1 9 5 8 / 5 9}$ & 5195 & 8.7 & 18.7 \\
\hline $\mathbf{1 9 5 9 / 6 0}$ & 5600 & 7.8 & 16.3 \\
\hline $\mathbf{1 9 6 0 / 6 1}$ & 5563 & -0.7 & 207.3 \\
\hline Total & & 63.2 & 18.8 \\
\hline Average & & 5.8 & \\
\hline$(\mathbf{1 9 5 0 / 5 1 - 1 9 6 0 / 6 1 )}$ & & & \\
\hline
\end{tabular}

Sources: Government of Burma 1955, 1962, 1963, Economic Survey of Burma. 
Dictatorship, disorder and decline in Myanmar

Appendix Table 4.5 Myanmar: GDP at 1969/70 constant prices, and GDI as a ratio of GDP, 1961/62-1970/71

\begin{tabular}{|c|c|c|c|}
\hline Fiscal year & GDP (million kyat) & $\begin{array}{c}\text { GDP change from previous } \\
\text { year (\%) }\end{array}$ & GDI/GDP ratio (\%) \\
\hline $\mathbf{1 9 6 1 / 6 2}$ & 7798 & 3.6 & 11.4 \\
\hline $\mathbf{1 9 6 2 / 6 3}$ & 8811 & 13.0 & 10.6 \\
\hline $\mathbf{1 9 6 3 / 6 4}$ & 8272 & -6.1 & 10.6 \\
\hline $\mathbf{1 9 6 4 / 6 5}$ & 9106 & 10.1 & 18.4 \\
\hline $\mathbf{1 9 6 5 / 6 6}$ & 8715 & -4.3 & 4.3 \\
\hline $\mathbf{1 9 6 6 / 6 7}$ & 8355 & -4.1 & 12.2 \\
\hline $\mathbf{1 9 6 7 / 6 8}$ & 9200 & 10.1 & 15.8 \\
\hline $\mathbf{1 9 6 8 / 6 9}$ & 9503 & 3.3 & 12.8 \\
\hline $\mathbf{1 9 6 9 / 7 0}$ & 9976 & 5.0 & 14.2 \\
\hline $\mathbf{1 9 7 0 / 7 1}$ & 10388 & 4.1 & 11.8 \\
\hline Total & & 34.6 & 122.0 \\
\hline Average & & 3.5 & 12.2 \\
\hline
\end{tabular}

Sources: Ministry of Planning and Finance, 1972/73 and 1975/76, Report to the Pyithu Hluttaw.

\section{Appendix Table 4.6 Myanmar: GDP at 1969/70 constant prices, and GDI as} ratio of GDP, 1970/71-1979/80

\begin{tabular}{|c|c|c|c|}
\hline Fiscal year & GDP (million kyat) & $\begin{array}{c}\text { GDP change from previous } \\
\text { year (\%) }\end{array}$ & GDI/GDP ratio (\%) \\
\hline $\mathbf{1 9 7 0 / 7 1}$ & 10388 & 4.1 & 11.8 \\
\hline $\mathbf{1 9 7 1 / 7 2}$ & 10641 & 2.4 & 12.2 \\
\hline $\mathbf{1 9 7 2 / 7 3}$ & 10538 & -1.0 & 10.8 \\
\hline $\mathbf{1 9 7 3 / 7 4}$ & 10812 & 2.6 & 10.2 \\
\hline $\mathbf{1 9 7 4 / 7 5}$ & 11101 & 2.7 & 9.0 \\
\hline $\mathbf{1 9 7 5 / 7 6}$ & 11562 & 4.2 & 9.9 \\
\hline $\mathbf{1 9 7 6 / 7 7}$ & 12265 & 6.1 & 10.3 \\
\hline $\mathbf{1 9 7 7 / 7 8}$ & 12996 & 6.0 & 13.0 \\
\hline $\mathbf{1 9 7 8 / 7 9}$ & 13843 & 6.5 & 18.2 \\
\hline $\mathbf{1 9 7 9 / 8 0}$ & 14562 & 5.2 & 22.3 \\
\hline Total & & 38.8 & 127.7 \\
\hline Average & & 3.9 & 12.8 \\
\hline
\end{tabular}

Sources: Ministry of Planning and Finance 1979/80 and 1984/85, Report to the Pyithu Hluttaw. 
Appendix Table 4.7 Myanmar: GDP at 1985/86 constant prices, and GDI as a ratio of GDP, 1980/81-1989/90

\begin{tabular}{|c|c|c|c|}
\hline Fiscal year & GDP (million kyat) & $\begin{array}{c}\text { GDP change from previous } \\
\text { year (\%) }\end{array}$ & GDI/GDP ratio (\%) \\
\hline $\mathbf{1 9 8 0 / 8 1}$ & 44338 & 7.9 & 21.5 \\
\hline $\mathbf{1 9 8 1 / 8 2}$ & 47157 & 6.4 & 22.9 \\
\hline $\mathbf{1 9 8 2 / 8 3}$ & 49714 & 5.4 & 22.2 \\
\hline $\mathbf{1 9 8 3 / 8 4}$ & 51878 & 4.3 & 18.0 \\
\hline $\mathbf{1 9 8 4 / 8 5}$ & 54437 & 4.9 & 15.1 \\
\hline $\mathbf{1 9 8 5 / 8 6}$ & 55989 & 2.9 & 15.5 \\
\hline $\mathbf{1 9 8 6 / 8 7}$ & 55397 & -1.1 & 12.7 \\
\hline $\mathbf{1 9 8 7 / 8 8}$ & 53178 & -4.0 & 11.6 \\
\hline $\mathbf{1 9 8 8 / 8 9}$ & 47141 & -11.4 & 12.8 \\
\hline $\mathbf{1 9 8 9 / 9 0}$ & 48883 & 3.7 & 9.2 \\
\hline Total & & 19.1 & 161.5 \\
\hline Average & & 1.9 & 16.1 \\
\hline
\end{tabular}

Sources: Ministry of Planning and Finance 1984/85, Report to the Pyithu Hluttaw; Central Statistical Organisation 1991, Statistical Yearbook.

\section{Appendix Table 4.8 Myanmar: GDP at 1985/86 constant prices, and GDI as a ratio of GDP, 1990/91-1999/00}

\begin{tabular}{|c|c|c|c|}
\hline Fiscal year & GDP (million kyat) & $\begin{array}{c}\text { GDP change from previous } \\
\text { year (\%) }\end{array}$ & GDI/GDP ratio (\%) \\
\hline $\mathbf{1 9 9 0 / 9 1}$ & 50260 & 2.8 & 13.4 \\
\hline $\mathbf{1 9 9 1 / 9 2}$ & 49933 & -0.7 & 15.3 \\
\hline $\mathbf{1 9 9 2 / 9 3}$ & 54757 & 9.7 & 17.6 \\
\hline $\mathbf{1 9 9 3 / 9 4}$ & 58064 & 6.0 & 12.4 \\
\hline $\mathbf{1 9 9 4 / 9 5}$ & 62406 & 7.5 & 12.4 \\
\hline $\mathbf{1 9 9 5 / 9 6}$ & 66742 & 7.0 & 14.2 \\
\hline $\mathbf{1 9 9 6 / 9 7}$ & 71042 & 6.4 & 12.3 \\
\hline $\mathbf{1 9 9 7 / 9 8}$ & 75123 & 5.7 & 12.5 \\
\hline $\mathbf{1 9 9 8 / 9 9}$ & 79460 & 5.8 & 12.4 \\
\hline $\mathbf{1 9 9 9 / 0 0}$ & 88157 & 10.9 & 13.4 \\
\hline Total & & 61.2 & 135.9 \\
\hline Average & & 6.1 & 13.6 \\
\hline
\end{tabular}

Sources: Central Statistical Organisation 1995, 1997 and 2003, Statistical Yearbook. 